UDC 541.64:678.8

\title{
FULLERENCE-CONTAINING COMPOSITES BASED ON ISOTACTIC POLYPROPYLENE
}

\author{
A.I.Dunyamalieva, N.I.Kurbanova, E.B.Zeynalov* \\ Institute of Polymer Materials, NAS of Azerbaijan \\ *M.Nagiyev Institute of Catalysis and Inorganic Chemistry, NAS of Azerbaijan
}

dunyamaliyeva89@list.ru

Reseived 22.12.2020

Accepted 26.02.2021

\begin{abstract}
In recent years much attention is paid to elaboration of polymer nanocomposites doped with functional nanofillers. Carbon nanoparticles including fullerenes are among them and they are considered as promising fillers bearing antiradical functionality. However the bad compatibility one of the constraining factors for wider use of these advanced polymeric materials. Compositions based on isotactic polypropylene (PP), fullerene soot (FS) and maleinized high density polyethylene (MA-g-PE) were prepared by the melt blending technique. Mechanical and thermal properties of the obtained PP/FS/MA-g-PE fragments nanocomposites have been thoroughly studied. It has been established that MA-g-PEfragments in PP matrix increase the mechanical and thermal properties of nanocomposites due to enhanced and improved compatibility of FS with the polymer matrix.
\end{abstract}

Keywords: isotactic polypropylene, composites, stabilization, antioxidant, fullerene soot, maleinized high density polyethylene.

doi

\section{Introduction}

The obtaining and industrial application of polymer nanocomposites is one of the important areas of nanotechnology. Polymer nanocomposites have improved properties compared to general polymers and their microcomposites [1].

Prevention of aging of polymer composite materials (PCM) as a result of long-term use, which has a special place in materials science is one of the important issues. Additives that increase the stabilizing activity of polymers are needed to slow down the aging process. Additives are needed to protect polymers from thermoxidative degradation. Research has been conducted to address this problem.

Much attention is paid to the development of nanocomposites using polymer matrices of various types including polyolefins and functional nanofillers. Carbon nanoparticles including fullerene are considered as promising polymer fillers. Nanosized additives - stabilizers, modifiers, antioxidants, flame retardants, plasticizers, etc. serve to improve the complex of functional properties of polyolefins $[2,3]$.
Studies on the antioxidant properties of fullerenes show that these molecular structures have potential stabilizing properties. Fullerene molecules have a hollow spherical shape covered by a system of connected single and double bonds combined in a condensed cyclic system. This electronic structure of fullerenes gives molecules the ability to bind nucleophilic particles such as electrons, free radicals, anions and hydrogen atoms, giving them strong electrophilic properties. The cost of e-greed is very high for fullerenes. Thus, the high cost of electron greed makes it possible to intensively combine organic radicals with many electron deficiencies such as alkyl radicals. Features such as high radical quenching ability, sensitivity to macroalkyl radicals, high diffusion coefficients, stability of fullerene radicals guarantee the use of fullerenes as the most powerful and universal nanostabilizerantioxidant for polymeric materials $[4,5]$.

The main advantage of fullerenes is the creation of new, higher quality materials by transferring most of their nanoscale properties to macro-sized composites. The inclusion of small amounts of fillers in polymers significantly changes their properties and opens up pro- 
spects for the creation of multifunctional materials [6].

To obtain a polymer blend or nanocomposite with the desired properties, compatibilization is an important issue. Actually, the differences in chemical nature between the polymers or the polymer matrix and the nanoparticles can lead to the formation of a systems with inadequate properties. Compatibilization gains importance in order to improve the properties. The degradation, which must be minimized, involves the decomposition of the organomodifier and the interactions among the degradation products and the polymers. These, together with the processing conditions, influence on the morphology and the properties of the material [7].

There is enough data in the literature on the effect of fullerenes on the technological and technical characteristics of polymers [8-13]. The aim of this work is to study the structure of fullerene soot(FS) and determine its effect on the structure, mechanical and thermal properties of isotactic polypropylene (PP).

\section{Experimental part}

Isotactic PP used in this work was supplied by "Kaplen" (Russia) (brand 01030) with a melt flow index, molecular mass and polydispersity index of (2.3-3.6) g/10 min, (2-3) $10^{5}$ and 4.5 respectevely.

The maleized high pressure polyethylene MPE containing 3\% maleic group was supplied by "Olenta" (Russia).

Fullerene soot (as produced) was provided by Aldrich Company (USA).

Two sets of polypropylene composites were prepared. First of all PP composites were obtained at the loading of FS nanofiller (0.1; $0.2 ; 0.5$ mass \%). Then, PP/FS composites were obtained in the presence of maleinized PE
(MPE) as a compatibilizer. The level of the used MPE compatibilizer was 1.0 mass\% [8] .

MPE was utilized as compatibilizer with a constant ratio of 1 mass \% for one composite. The composites were prepared by melt-mixing technique using a heated two-roll mixer at 160 $165^{\circ} \mathrm{C}$. PP was charged into the mixer, after 5 minutes FS was added and the mixing process was continued for another $3 \mathrm{~min}$, at $11 \mathrm{~min}$ MPE was added, the mixing process was continued for another $3 \mathrm{~min}$ for a total mixing time of $14 \mathrm{~min}$. The resulting mixtures were compressed for $10 \mathrm{~min}$ at a temperature of $190^{\circ} \mathrm{C}$ and pressure of $10 \mathrm{MPa}$.

Physico-mechanical properties of the obtained compositions were determined on a RMI-250 device.

The thermal stability of the studied samples of PP compositions was studied on a Q$1500 \mathrm{D}$ derivatograph manufactured by MOM (Hungary). The tests were carried out in an atmosphere of air in a dynamic mode with a sample heating of $5 \mathrm{grad} / \mathrm{min}$ from 20 to $500^{\circ} \mathrm{C}, 100$ mg sample, channel sensitivity DTA $-250 \mu \mathrm{V}$, TG -100, DTG - $1 \mathrm{mV}$.

\section{Results and discussion}

Compositions based on isotactic polypropylene (PP), fullerene soot (FS) and maleinized PE (MA-g-PE) were obtained. Fheir mechanical and thermal properties have been studied.

The results for PP/FS and PP/FS/MPE composites are clted in Table 1.

The insertion of 0.1 mass $\%$ FS into the composition leads to a decrease in the tensile strength index from 31.41 to $29.12 \mathrm{MPa}$ and the relative elongation from 34 to $32 \%$, that indicates poor compatibility between the components of the PP composition.

Table 1. Mechanical properties of nanocomposites

\begin{tabular}{|l|c|c|c|}
\hline $\begin{array}{c}\text { Compositions } \\
(\text { mass } \%)\end{array}$ & $\begin{array}{c}\text { The tensile strength, } \\
\sigma_{\mathrm{p}}, \mathrm{MPa}\end{array}$ & $\begin{array}{c}\text { Elongation at break }\left(\varepsilon_{\mathrm{p}}\right) \\
\%\end{array}$ & $\begin{array}{c}\text { Vicat heat reistance, } \\
{ }^{0} \mathrm{C}\end{array}$ \\
\hline PP (100) & 31.41 & 34 & 165 \\
\hline PP/FS (100/0.1) & 29.12 & 32 & 173 \\
\hline PP/FS (100/0.2) & 31.28 & 36 & 178 \\
\hline PP/FS (100/0.5) & 21.06 & 20 & 175 \\
\hline PP/ FS/ MPE(100/02/1.0) & 34.72 & 40 & 180 \\
\hline
\end{tabular}


An increase in the PS concentration to 0.2 mass\% leads to an increase in the strength of the composite $(31.28 \mathrm{MPa})$ and relative elongation (36\%), that is apparently due to the crystal structure of the composite, an increase in the degree of its crystallinity and, thus, an improvement in the physical and mechanical properties. The insertion of 0.5 mass $\%$ PS into the composition leads to a decrease in both the tensile strength index (21.06 $\mathrm{MPa})$ and the deformation value upon rupture of the composite $(20 \%)$, that is probably due to the aggregation of nanoparticles, that leads to the formation of microdefects in the bulk of the polymer matrix.

In order to improve the compatibility between the components of the PP composition, a compatibilizer was inserted into its composition - maleinized high-pressure polyethylene (MPE), containing $3.0 \%$ of maleic groups, the presence of which in the composite structure affects the interfacial region, contributes to an even greater system structuring. The presence of maleic groups in the composition of the MPE creates the possibility of its interaction along the double bonds of the FS, which further strengthens the structure of the nanocomposite.

The insertion of 1.0 mass\% MPE into the composition of the PP/FS leads to an increase in the strength of the composite (33.72 $\mathrm{MPa}$ ) and relative elongation (40\%), which is apparently due to the synergistic effect of the interfacial interaction of fullerene-containing nanoparticles in the PP matrix with the components of the polymer composition - maleic MPE groups, the mutual effect of which contributes to an increase in both the deformation value and the strength index [15].

The study of the Vicat heat resistance of the obtained compositions showed that the insertion of the FS nanofiller into the composition of PP promotes an increase in the heat resistance index from 165 to $175-178^{\circ} \mathrm{C}$. The combined use of FS and MPE in a polypropylene composition leads to an even greater value of the heat resistance index $-180^{\circ} \mathrm{C}$.

The chemical changes due to the oxidative environment could be detected differently by the analyzer, and it could become a very useful information regarding the characterization of a sample. Thermal stability of the studied samples based on PP containing FS and MPE was estimated by the activation energy (Ea) of thermooxidative destruction calculated by double logarithmizatio[16] according to the TG curve, by the temperature of $10 \%\left(T_{10}\right), 20 \%\left(T_{20}\right)$ and $50 \%$ $\left(T_{50}\right)$ decay of the studied samples, as well as by their half-life time $-\tau_{1 / 2}$. The resulting derivatographic research data are shown in Table 2.

It is shown that the introduction of MPE into the composition of the PP/FS composition increases the half-life temperature of the samples: $T_{50}$ from 335 to $375^{\circ} \mathrm{C}$; the half-life $\tau_{1 / 2}$. increases from 63.2 to $72.8 \mathrm{~min}$.

The effective activation energy of thermal-oxidative degradation is often a good indicator for the heat stability of a compositions. The activation energy of PP is $145.45 \mathrm{~kJ} / \mathrm{mol}$ and that of PP/FS and PP/FS/MPE in the range of 155.02 to $210.52 \mathrm{~kJ} / \mathrm{mol}$. The results obtained indicate the successful grafting of MPE molecules on the PP/FS surface. As can be seen, the $\mathrm{PP} / \mathrm{MPE} / \mathrm{FS}$ is thermally significantly stable than the blank and non-maleinized samples.

Derivatographic studies have shown that the introduction of MPE into the composition of the PP/FS composition improves the thermaloxidative stability of the obtained nanocomposites.

Numerous experimental data on the mechanical, strength, relaxation, and other properties of polymer-polymer, polymer-filler mixtures are explained in terms of the concept of the presence of an interfacial layer [17].

Table 2. TGA results of nanocomposites

\begin{tabular}{|l|c|c|c|c|c|}
\hline \multicolumn{1}{|c|}{ Compositions (mass $\%)$} & $T_{10}, \%$ & $T_{20}, \%$ & $T_{50}, \%$ & $\tau_{1 / 2}, \min$ & $E_{\mathrm{a}}, \mathrm{kJ} / \mathrm{mol}$ \\
\hline PP (100) & 135 & 265 & 335 & 63.2 & 145.45 \\
\hline PP/FS (100/0.1) & 270 & 305 & 365 & 68.3 & 189.16 \\
\hline PP/FS (100/0.2) & 280 & 310 & 370 & 70.5 & 200.37 \\
\hline PP/FS (100/0.5) & 260 & 310 & 355 & 67.2 & 155.02 \\
\hline PP/FS/ MPE (100/0.2/1.0) & 290 & 320 & 375 & 72.8 & 210.52 \\
\hline
\end{tabular}


The properties of polymer composites are significantly affected by the supramolecular structure of the polymer (the size of spherulites, the degree of crystallinity, the presence of $\mathrm{C}=\mathrm{O}$ groups and different branchings, etc.) and the interfacial interaction at the phase boundary [18].

The fullerencontaining nanoparticles used in this work, located at the interface between the structural elements of PP and MPE, contribute to the formation of heterogeneous nucleation centers in the composition of the melt, which, in the process of stepwise cooling of the nanocomposite, contribute to the increase of crystallization centers, whot generally leads to an improvement in the crystallization process and the formation of a relatively fine spherulite structure.

The results show that small amounts of nanofiller $(0.1-0.2$ mass $\%)$ introduced into the polymer obviously play the role of structureforming agents - artificial crystallization nuclei, which contributes to the formation of a finespherulite structure in the polymer, characterized by improved physicol-mechanical and thermal properties of the resulting nanocomposite [19].

\section{Conclusion}

The effect of a nanofiller - fullerene soot (FS) and a compatibilizer - maleinized highpressure polyethylene (MPE) on the mechanical and thermal properties of a composite based on isotactic polypropylene (PP) has been studied.

An improvement in the strength and deformation parameters, as well as the thermaloxidative stability of the obtained nanocomposites, was revealed.

It was shown that the insertion of FS into the composition of the PP together with MPE leads to a significant increase in the ultimate strength and relative elongation of the composite, which is apparently due to with the synergistic effect of the interfacial interaction of fullerene-containing nanoparticles in the PP matrix with the components of the polymer composition - maleic groups of the MPE, the mutual influence of which contributes to an increase in both the deformation value and the strength index.

Derivatographic studies have shown that the introduction of MPE into the composition of the PP/FS composition improves the thermaloxidative stability of the obtained nanocomposites.

\section{References}

1. Paul D.R., Robeson L.M. Polymer nanotechnology: Nanocomposites. Polymer. 2008. No 49. P. 3187-3204.

2. Mikhaylin Yu.A. Polimernyye nanokompozitsionnyye materialy. Polimernyye materialy. 2009. No 7. C. 10-13.

3. Galvan Y.P., Alperovich I., Zolotukhin P., Prazdnova E., Mazanko M., Belanova A., Chistyakov V. Fullerenes as anti-aging antioxidants. Current aging science. 2017. No 10. P. 56-67.

4. Tuychiyev SH.T., Ginzburg B.M., Rashidov D.R., Tabarov S.KH., Istamov F.KH. Vliyaniye fullerena C60 na svetostoykost' polietilena nizkoy plotnosti i atakticheskogo polimetilmetakrilata. Dokl. AN Respubliki Tadzhikistan. 2015. № 158. C. 63-66.

5. Zeinalov E.B., Kobmehl G. Fullerene C60 as an antioxidant for polymers. Polymer Degradation and Stability. 2001. No 71. P. 197-202.

6. Zeynalov E.B., Allen N.S., Salmanova A., Radical N.I. Scavenging efficiency of different fullerenes C60-C70 and fullerene soot. Polymer Degradation and Stability. 2009. No 94. P. 1183-1189.

7. Mistretta M.C., Ceraulo M., La Mantia F.P., Morreale M. Compatibilization of polyethyl-ene/polyamide 6 blend nanocomposite films. Polymer Composites. 2015. No 36. P. 92-99.

8. Penkova A.V, Acquah S.F, Piotrovskiy L.B, Markelov D.A, Semisalova A.S, Kroto H.W. Fullerene derivatives as nano-additives in polymer composites. Russ Chem Rev. 2017. V. 86. No 6. P. 530566.

9. Monakhova T.V., Nedorezova M.P., Margolin A.L., Palaznik O.M., Popov A.A., Emanuel' O.N., Kolyadina M.N. Nanokompozity na osnove fullerenov S60/S70 i polipropilena. International Congress "Neurosciece for Medisine and Psychology". Sudak, Crimea, Russia, May 30-June 10, 2018. C. 334-335.

10. Palaznik O.M, Nedorezova M.P., Pol'shchikov S.V., Klimkina A.N., Shevchenko V.G. Krashennikov V.G., Monakhova T.B., Arbuzov A.A. Polucheniye polimerizatsiyey in situ i svoystva kompozitsionnykh materialov na osnove polipropilena i gibridnykh nanouglerodnykh napolniteley. Vysokomolek. soyed. ser. B. 2019. T. 61. № 2. C. 144-160 
11. Pol'shchikov S.V., Nedorezova P.M., Monakhova T.V., Klyamkina A.N., Shchegolikhin A.N., Krasheninnikov V.G., Muradyan V.Ye., Popov A.A., Margolin A.L. Kompozitsionnyye materialy na osnove fullerenov $\mathrm{S} 60 / \mathrm{S} 70$ i polipropilena, poluchennyye polimerizatsiyey in situ. Vysokomolek. soyed. Ser. B. 2013. T. 55. № 5. C. 582-590.

12. Badamshina. E.R., Gafurova M.P. Modifikatsiya svoystv polimerov putem dopirovaniya fullerenom S60. Vysokomolekulyarnyye soyedineniya. Ser. B. 2008. T. 50. № 8. C. 1572-1584.

13. Dong Wan, Yujie Wang, Xin Wen, Jian Qiu. The rheological, thermostable, and mechanical properties of polypropylene/fullerene C60 nanocomposites with improved interfacial interact ion. Polymer Eng. and Sci. July 2012. V. 52. No 7. P. 1457-1463.

14. Zeynalov E.B., Kurbanova N.I., Dunyamalieva A.I. Mechanical and thermal properties of fullerene-containing polypropylene composites. X Int. scientific-technical conf." Advance in Petroleum and Gas Industry and Petrochemistry" Proceed- ings. Lviv, May 18-23, 2020. APGIP-10 Львів Видавництво Львівської політехніки. 2020. Р. 151-152.

15. Ragunathan S., Mustaffa Z., Kamarudin H., Sam S.T., Ismail H. The effect of polypropylene maleic anhydride on polypropylene/(recycled acrylonitrile butadiene rubber)/(sugarcane bagasse) composite. J. Vinyl and Additive Technology. 2017. № 23. P. 228-233.

16. Tekhnicheskiye svoystva polimernykh materialov: Uchebno-spravochnoye posobiye. Pod obshchey red. prof. V.K.Kryzhanovskogo. SPb.: Professiya. 2007. $240 \mathrm{~s}$.

17. Pomogaylo A.D. Molekulyarnyye polimerpolimernyye kompozitsii. Sinteticheskiye aspekty Uspekhi khimii. 2002. T. 71. № 1. S. 5-38.

18. Kuleznev V.N. Smesi i splavy polimerov. Konspekt lektsiy. SPb.: Nauchnyye osnovy i tekhnologii. 2013. $216 \mathrm{~s}$.

19. Kakhramanly Yu.N. Nesovmestimyye polimernyye smesi i kompozitsionnyye materialy na ikh osnove. Baku: Elm, 2013. 152 s.

\section{FÜLLERENTORKIBLI IZOTAKTIK POLIPROPILEN OSASLI KOMPOZITLӘR}

\section{A.I.Dünyamalieva, N.I.Kurbanova, E.B.Zeynalov}

Son illərdə funksional nanodolduruculardan istifadə etməklə polimer nanokompozitlərin hazırlanmasına daha çox diqqət yetirilir. Füllerenlər də daxil olmaqla karbon nanohissəcikləri antiradikal funksiyası olan perspektivli doldurucular kimi qəbul edilir. Lakin zəif uyğunluq bu qabaqcıl polimer materialların daha geniş istifadəsi üçün məhdudiyyətlər yaradır. İzotaktik polipropilen (PP), fülleren dudası (FD) və maleinləşdirilmiş yüksək sıxlıqlı polietilen (MPE) əsaslı kompozisiyalar ərintidə qarışdırma metodu ilə hazırlanmışdır. Alınan PP/FD/MPE nanokompozitlərinin mexaniki və termiki xassələri ətraflı öyrənilmişdir. PP matrisindəki MPE fraqmentləri, FD ilə polimer matris arasındakı uyğunluğu artırmış, nəticədə nanokompozitlərin mexaniki və istilik xüsusiyyətlərində yüksəlmə müəyyən edilmişdir.

Açar sözlor: izotaktik polipropilen, kompozitlar, stabilloşmə, antioksidant, fülleren dudası, maleinloşdirilmiş yüksək slxliqli polietilen.

\section{ФУЛЛЕРЕНСОДЕРЖАЩИЕ КОМПОЗИТЫ НА ОСНОВЕ ИЗОТАКТИЧЕСКОГО ПОЛИПРОПИЛЕНА}

\section{А.И.Дунямалиева, Н.И.Курбанова, Э.Б.Зейналов}

В последние годы большое внимание уделяется разработке полимерных нанокомпозитов, допированных функциональными нанонаполнителями. Среди них - углеродные наночастицы, в том числе фуллерены, которые рассматриваются как перспективные наполнители с антирадикальной функциональностью. Однако плохая совместимость является одним из сдерживающих факторов для более широкого использования этих современных полимерных материалов. Методом смешения в расплаве были получены композиции на основе изотактического полипропилена (ПП), фуллереновой сажи (ФС) и малеинизированного полиэтилена высокого давления (МПЭ). Изучены механические и термические свойства полученных нанокомпозитов ПП/ФС/МПЭ. Установлено, что фрагменты МПЭ в матрице ПП повышают механические и термические свойства нанокомпозитов за счет улучшения совместимости ФС с полимерной матрицей.

Ключевые слова: изотактический полипропилен, композиты, стабилизащия, антиоксидант, фуллереновая сажа, малеинизированный полиэтилен высокого давления. 